\title{
ResearchArticle
}

\section{Character association in taramira (Eruca sativa L.) under three environment conditions}

\author{
B.L. JAT AND M.L. JAKHAR
}

\begin{abstract}
SUMMARY
Forty two genotypes of taramira (Erucasativa Mill.) were evaluated for character association analysis of seed yield and its related traits over three different environments created by three dates of sowing during Rabi 2009-10. Environment wise analysis of phenotypic correlation revealed that in first environment seed yield were positive correlated with all characters except seed per siliquae and test weight. In second environment seed yield are positive correlated with days 50 per cent flowering, days to maturity and seed per siliquae and negative correlated with plant height, primary branches per plant, secondary branches per plant, siliquae per plant, test weight and oil content. In third environment seed yield were positive correlated with days to 50 per cent flowering, secondary branches per plant,siliquae per plant seed per siliquae, test weight and oil content and negative correlated with days to maturity, plant height and primary branches per plant.
\end{abstract}

Key Words : Eruca sativa, Phenotypic correlation

How to cite this article : Jat, B.L. and Jakhar, M.L. (2015). Character association in taramira (Eruca sativa L.) under three environment conditions. Internat. J. Plant Sci., 10 (1): 49-52.

Article chronicle : Received : 30.09.2013; Revised : 20.11.2014; Accepted : 03.12.2014

Email: babu_agrotech@yahoo.co.in

\section{Address of the Co-authors:}

M.L. JAKHAR, Department of Plant Breeding and Genetics, S.K.N. College of Agriculture, JOBNER (RAJASTHAN) INDIA 